\title{
Users' Satisfaction With Tun Hussein Onn Library (THOL) Services
}

\author{
Mohd Shamsul Mohd Shoid, Phd (Corresponding author) \\ Faculty of Information Management \\ Universiti Teknologi MARA (UiTM), Selangor \\ Malaysia \\ E-mail: shamsulshoid@salam.uitm.edu.my
}

Khairunnisa Rubian

Institute of Language and Literature

Malaysia

Noor Harun Abdul Karim, Phd

Department of Psychology

International Islamic University Malaysia (IIUM)

Malaysia

Norliya Ahmad Kassim, Phd

Faculty of Information Management,

Universiti Teknologi MARA (UiTM), Selangor

Malaysia

Received: August 5, 2018 Accepted: September 25, 2018 Published: September 30, 2018 doi:10.5296/ijld.v8i3.13733 URL: https://doi.org/10.5296/ijld.v8i3.13733 


\begin{abstract}
User Satisfaction is defined as a personal emotional reaction to services or products provided by the company or institution. In order to allocate better services and resources, it would be important to the library management to identify students' priorities among various services quality. Hence, the purpose of the study was to explore the perceptions regarding users' satisfaction and users' loyalty on Tun Hussein Onn Library (THOL) library services among Sunway University students. The target population for this study was 250 from both undergraduate and postgraduate students from several courses and year of study. One hundred and eighty $(72 \%)$ of the questionnaires were returned and useable for further analysis. From the findings, the results of running an independent sample t-test were found to be not statistically significant difference regarding users' satisfaction and users' loyalty towards Tun Hussein Onn Library services between male and female. Besides, The results of running a One-Way ANOVA showed that there was a statistically significant mean difference between first year students, second year students and those in third year and above with regard to their scores on users' satisfaction. In addition, the results also showed that there was a statistically significant mean difference between first year students, second year students and those in third year and above with regard to their scores on users' loyalty. However, there was no statistically mean difference between pre-university student, diploma level and baccalaureate level students with regards to their score on users' satisfaction dimension. Besides, the results also showed that there was no statistically mean difference between pre-university students, diploma level and baccalaureate level students with regards to their scores on users' loyalty dimension. The outcome of the study is expected to assist the library in order to meet the user satisfaction in using library services.
\end{abstract}

Keywords: Users satisfaction, user loyalty, library services, academic library

\title{
1. Introduction
}

In library and information science perspectives, information is a consumable product that can only be consumed together with certain information delivery systems and/or services. The satisfaction of library users is a function of the quality of information product(s) received, the quality of information system and library services provided to access the information product. Therefore, satisfaction is a function of three main sources - quality of the information product, the information system and the services that make the information product available. These three levels of measure of satisfaction are defined by the information resources, facilities and services in this study. These sources of satisfaction, when properly harnessed may contribute to users' overall satisfaction. The accuracy, completeness, precision, and relevance of the information materials obtained from public library by a user are measures of the product performance.

Community in Sunway University and Colleges used the library resources, facilities and services. These users include undergraduates, postgraduates, lecturers (full time/part time), admin staff, staff of Sunway Group and alumni. Large numbers of users also turn to Tun Hussein Onn Library to satisfy their desire for knowledge or to obtain materials for some kind of leisure-time activities. A library may meet user's information needs by acquiring, organising 
and making available relevant information resources backed by appropriate facilities and delivered by means best known to them, which could be manual or through Information and Communication Technologies (ICTs). For any academic library to perform well and meet the needs of the users on this modern time, it is necessary for the academic library to embrace the use of information and communication technology. The role of ICT in the effective utilisation of libraries has been stressed in the literature, particularly in academic libraries. In a survey conducted by Ojo and Akande (2005), it was gathered that students use internet sources and e-mail more than other sources. Other electronic information resources used by students in order of importance include CD-ROM, e-Journal, etc.

A lot of academic information can be received using electronic resources both inside and outside the library. This may be the reason why they are more popular compared to other resources. However, lack of computer and IT skills, time consuming, limited access to computer terminal and too much information retrieval, using electronic resources, often detracts from doing work (Ojo \& Akande, 2005). These challenges among users may deter them from using electronic information sources. The success of online searching depends on the ability of the user or the information scientist to perform the search in the best possible way.

Academic library exists to satisfy and fulfill the students' and academicians' need. In this context, users' satisfaction refers to how users judge the services of academic libraries. Indeed, it refers to whether users of Tun Hussein Onn Library get the desired information resources, facilities and services expected to be provided by the academic libraries. Hence, in recent times, evaluating users' satisfaction with the information resources, facilities and services of public libraries have become a major concern and an integral part of library and information science is practitioners (Ogunsola, 2004). This is because the ultimate aim of all libraries as a service oriented organization is to satisfy the needs of its clients. Thus, users' satisfaction with the information resources, facilities and services provided by libraries whether public or academic has become the melting pot of the present day librarianship and information science (Saliu, 2002).

Facilities and services are important in the academic library services, the extent to which they satisfy users' information needs is fundamentally more important. This is because the ultimate goal of academic libraries is to bring about higher users' satisfaction. Thus, it becomes pertinent to determine the extent to which users are satisfied with the information resources, facilities and services of academic's libraries. Academic libraries generally serve a wide range of users, such as; academicians, students from all levels such as Diplomas, Bachelors, Maters, Doctor of Philosophy and researchers from various fields. Due to this fact, Tun Hussein Onn Library has vital roles to play in information dissemination at the grassroots to meet the information needs of each of these groups. Thus, Tun Hussein Onn Library must be proactive, vibrant and abreast of the latest developments in information dissemination to maintain relevance and keep up with the multivarious needs and expectations of library users. It is therefore important that the Tun Hussein Onn Library should be able to provide the right materials to meet the information needs of users.

Besides, this study seeks to explore the students' perceptions on users' satisfaction of THOL library services and facilities provides by the library. 


\section{Literature Review}

\subsection{User Satisfaction}

Cullen (2001), Andaleeb and Simmonds (1998), Bergman and Holden (2010) and Niyonsenga and Biziman (1996) agreed that user satisfaction is one method of evaluating the effectiveness of the library services and library collections. A user's point of view may provide insights for service providers and point to change in the service in order to make it easier to use, more welcoming or enhance the user's experience. In addition, user satisfaction is a key variable in accessing and evaluating the services and collections provided by the library.

User satisfaction may be affected by the previous happenstances with a library, current information use environment, the characteristics of the information product or service, or current information gap. Thus, user satisfaction is related to the benefit that is perceived to be gained in using the library services. The benefits shall be measured in actual cost savings, in term of willingness of user to pay in terms of real price, cost savings in dollars or time, decrease in uncertainty, decrease in duplication of work or potential loss of productivity (Miller, 2004).

Previous study by Tessier, Crouch and Artherton (1977) has stated that user satisfaction as a concept and it was ultimately a state of experienced inside the user's head and therefore was a response that may be both intellectual and emotional. User satisfaction can also be considered as the basic concept of IR (Information Retrieval) system evaluation that could not be ignored in any experiment (Jones, 1981). The following advantages of user satisfaction are; it takes explicit account of users and their subjective evaluation of various aspects of the IR interaction, it focuses on multidimensional evaluation of the interactive processes and it also recognizes user and request characteristics as among possible influencing factors in user evaluation.

Customer satisfaction or user satisfaction has been defined as the summary psychological state resulting when the emotion surrounding disconfirmed expectations is coupled with a consumer's or users prior feelings about the experience (Oliver, 1981). Bhattacherjee (2001) affirmed that user satisfaction is the outcome of an evaluative process, where the users examine the results of their prior service use and decide whether or not to continue using the service. Besides, user satisfaction level reflects how successfully and effectively a company or organisation implements its business operations. Thus, it is important to understand the customer satisfaction, since it is associated with other crucial constructs such as user loyalty in the context of information systems design (Melone, 1990; Zviran, Glezer, \& Avni, 2001; Klenke, 1992).

Liu and Yen (2010) indicated that user satisfaction is regarded as users can get more benefits than their cost. Thus, user satisfaction plays the important role in total quality management. In contrast with other traditional performance measures, user satisfaction is probably less sensitive to seasonal fluctuations, changes in costs or changes in accounting practices (Kotler, 2006). Therefore, many researchers consider user satisfaction or customer satisfaction to be 
the best indicator of a company's future profit (Adeniran, 2011).

DeLone and McLean (1992) presented a user satisfaction model based on the notion that the quality of the system such as information and technical quality affects user satisfaction. Findings concerning the effect of the quality of attributes of a system on user satisfaction can be applied to maximize system value by considering these from the user's perspective (Cho \& Hong, 2013).

\subsubsection{User Satisfaction and Gender}

Hekman, Aquino, Owens, Mitchell, Schilpzand and Leavitt (2010) stated that based on their theoretical arguments supporting the influence of gender bias in customer satisfaction judgements were based on the idea that observes (e.g. customers). In addition it has preconceived expectations about others depending on whether the person being observed belongs to high or low status demographic group (Berger, Corner, \& Fisek, 1974; Berger, Fisek, Norman, \& Zelditch, 1977).

In sum, customer satisfaction judgments are likely to be highly vulnerable to racial and gender biases because customers are usually anonymous, asked to make summary judgments rather than provide accurate recall of performance-related behaviors, and are untrained in techniques that might help them overcome non-conscious biases. Arguments lead us to expect that, in general, employees belonging to low-status demographic groups (i.e., women, racial minorities) will receive lower customer satisfaction scores than employees belonging to high-status demographic groups. But even if we found evidence for this difference, it would not demonstrate the operation of bias in customer judgments because it may be that the lower customer satisfaction judgments received by members of lower status demographic groups may in fact indicate lower levels of true performance. Logically, customer satisfaction judgments should be at least partly influenced by employee objective performance (Wherry \& Bartlett, 1982).

According to Wright, Craig, Campbell, Schaefer and Humble (2006) a significant difference between female and male reporting of satisfaction was found in the unadjusted analyses with males showing greater levels of satisfaction than females $(\mathrm{P}<.05)$. This difference became smaller for both inpatient and outpatient services, after adjusting for covariates. For six of the inpatient dimensions (Transitions, Physical Comfort, Involvement Family and Friends, Courtesy, Coordination and Access) males had higher satisfaction than females after statistical adjustment.

Tyler and Hastings (2011) stated that an independent samples $t$ test was conducted to determine if gender influenced virtual library's patron's satisfaction with online resources. Results indicated that females were significantly more satisfied with the online library resources than males, $t(177)=-2.766, \mathrm{p}<0.05$.

\subsubsection{User Satisfaction and Year of Study}

A study by Chia and Edzan (2008) showed that students were generally satisfied with the Chinese studies' printed books which adequately met the needs of general reading purpose 
and undergraduate first year. However, when the undergraduate student moved to year 2 and year 3, they seemed to be less satisfied with the printed books collections.

According to Kassim (2009) there were differences in satisfaction between faculties which showed that on the satisfaction on services, infrastructure/place/space, collection/information, on the average, the final year students of Information Studies (IS) from are relatively more satisfied than final year students of Administrative Science and Public Policy (AM) and final year students of Law (LW). Therefore, in all of the three aspects of the library, Information Studies (IS) students are more likely to be satisfied than those from Administrative Science and Public Policy (AM) and Law (LW) in that order.

\subsubsection{User Satisfaction With Library Services and Facilities}

Andaleeb and Simmonds (1998) argued that there were two major elements that needed to be focused by the academic libraries and the librarians; resources and demeanour. By providing customer satisfaction, the resource strategy was much vital because the academic library users frequented their libraries to find solutions to their academic problems and needs. Nowadays, the dynamic environment of information availability, does not only represents the size of the library's collection but rather, also provides a variety of other resources and making access to these resources is the key to the resources adequacy judging. The remaining is connected to academic institutions curriculum such as teacher's resources needs and research agenda and student preference for how the needed information is packaged (i.e. CD-ROMS, journals, microfiche, audio-visual, internet, etc.).

According to Chia and Edzan (2008) users were generally most satisfied with of the services and facilities that been provided by the Universiti Malaya Library. However, there was dissatisfaction detected as the library professional needed to participate in material selection. In this instance, materials selection shall be done based on the lecturers' recommendations or based on their reading list. Besides, they were less satisfied on the inter-library loan services provided by the UM library. Students responded that they had never used the inter-library loan services. The most frequently used services in UM Library were; general reference service; library guides on library collection or OPAC; short term and long term facilities.

A study by the Walton and Leahy (2013) bund that $94 \%$ of people who completed the survey agreed that the library was providing a good level of service. This survey had also provided valuable intelligence that had already been used to inform the Library refurbishment and will be used in other service development. This complexity was illustrated by the changing way the Library building had been used over the years. The higher satisfaction levels for most services achieved in 2012 compared to the 2009 survey was especially welcomed. It was noted that the changes in opening hours in 2011 had an immediate positive effect. It was also very gratifying that services where there is personal contact with Library staff (enquiry/information desks and academic librarians) have high satisfaction levels.

\subsubsection{User Satisfaction With Library Resources}

Seneviratne (2006) identified that the traditional collections of books and journals were the major reason most users came to the library. Sixty five percent of the users stated that they 
did not participate in the material selection process of the library. Thus, the relationship between the level of awareness of users about a particular resource and the satisfaction attributed to that resource was meaningful. The assessment of the services and its effectiveness measured to a greater extent by user responses must not be overlooked. It is important to know that users were unaware of several services provided by the library. In addition, user education was very valuable to produce a satisfied library user. This may enabled the students to make more efficient, independent use of the stock and the services. It was revealed that users were unaware of the online public access catalogue of the library by analysing the $36.5 \%$ of no comment responses on the catalogue.

Based on the responses, the respondents preferred print books $(118,88 \%)$ compared to print journals $(14,10.4 \%)$ and electronic resources $(2,1.5 \%)$. This may be caused by the absence of relevant or insufficient print journals and electronic resources available for usage in the University of Malaya Library. This also reinforced the fact that Chinese was a text based society which preferred books rather than electronic resources (Chia \& Edzan, 2008; Woo 2005).

Resources were ranked in importance levels, a key finding was that the two core of providing textbooks and a wide range of books were placed 1 st and 2 nd respectively in terms of overall importance. Those ranked of lowest importance were providing print journals (14th) and workshops (15th). This endorses the Library's strategic move to provide e-journals rather than print versions (Walton \& Leahy, 2013).

Abagai (1993) noted that the use of the library by users and indeed their satisfaction with library services depend on the availability of the suitable learning materials, accommodation and competent staff in the library. In addition, the main objective of any library was to support the parent institution; such as achieved through the systematic acquisition and organisation of all forms of recorded information in variety of fields regarding to the institution goals and making it available to all the members' of the institution

\section{Methodology}

For the purpose of this research, a self-reported questionnaire was designed to obtain quantitative data from the respondents. Target population size for this study was 250 from both undergraduates and postgraduates students from several courses and year of study. From the feedback, one hundred and eighty $(72 \%)$ of the questionnaires were returned and useable for further analysis The questionnaire has been constructed using the 6 point scale $(1=$ don't know or not applicable to $6=$ very satisfied) and 7 point Likert scale ( 1 strongly disagree to 7 $=$ strongly agree, $1=$ completely dissatisfied to $7=$ completely satisfied, $1=$ very poor to $7=$ very excellent, $1=$ very far away to $7=$ very close, $1=$ very poor to $7=$ very excellent). For data analysis, descriptive statistics include frequency and percentage while the inferential statistics include independent samples $t$-test and ANOVA (One - Way Analysis of variance). 


\section{Macrothink}

\section{Findings and Results}

\subsection{Profile of Respondents}

The findings showed that more than half of the respondents are female. $(57.2 \%)$ whilst the remaining $42.8 \%$ are male. Hence the majority of the respondents in this study were female library users. Besides, The findings showed that the majority of respondents are those pursuing a diploma in their respective areas and interest $(52.2 \%)$. This is followed by those pursuing their baccalaureate degree in their respective areas of interest (42.2\%). Only 5.6\% of the respondents are pre-university students. Majority of respondents are from $3^{\text {rd }}$ year and higher $(42.8 \%)$. This is followed by respondent from $2^{\text {nd }}$ year $(38.3 \%)$. Only $18.9 \%$ of the respondents are $1^{\text {st }}$ year students.

\subsection{Construct Validation of User Satisfaction With Library Service Exploratory Exploratory Factor Analysis}

To assess the construct validity of the "user satisfaction with library services" construct, an exploratory factor analysis using principal component analysis was employed on the 4-item scale. Using a factor loading coefficient of 0.40 or greater as a criterion for deeming a factor loading as practically significant yielded a single factor solution (eigenvalue more than 1.00) that collectively explained $65.8 \%$ of the variance in the construct "user satisfaction with library services". The results of running the exploratory factor analysis using principal component analysis is visually depicted in Table 1 below.

Table 1. User satisfaction with library services

\begin{tabular}{clc}
\hline No. & \multicolumn{1}{c}{ Items } & $\begin{array}{c}\text { Factor Loading } \\
\text { Coefficient }\end{array}$ \\
\hline $1 \quad \begin{array}{l}\text { Considering all your experience with Tun Hussein Onn Library, how satisfied are } \\
\text { you in general? (expert) }\end{array}$ & 0.78 \\
$2 \quad \begin{array}{l}\text { To what degree do you consider that Tun Hussein Onn Library fulfils your } \\
\text { expectations? (expect) }\end{array}$ & 0.82 \\
3 & $\begin{array}{l}\text { Imagine a library which is perfect in all aspects. How close to this ideal do you } \\
\text { consider Tun Hussein Onn Library to be? (perfect) }\end{array}$ & 0.82 \\
4 & How would you rate the service provided by the library? (service) \\
\hline
\end{tabular}

Percent of Variance Explained $=65.80 \%$.

\subsection{Internal Reliability Test Using Cronbach's Alpha}




\section{Macrothink Institute ${ }^{\text {TM }}$}

Before a new composite variable is computed, the four-item scale was submitted to an internal reliability assessment test using Cronbach's internal reliability coefficient alpha. The results of running Cronbach's internal reliability test resulted in all the four items having a Cronbach's alpha value of 0.83 . Dropping any of the 4 items would not increase the alpha coefficient to anything greater than 0.83 . Subsequently, the four items were averaged to create a composite variable called "user satisfaction with library services".

Table 2. Internal reliability assessment of user satisfaction with library services

\begin{tabular}{clc}
\hline No. & \multicolumn{1}{c}{ Items } & $\begin{array}{c}\text { Cronbach's Alpha if } \\
\text { Item is Deleted }\end{array}$ \\
\hline $1 \quad \begin{array}{l}\text { Considering all your experience with Tun Hussein Onn Library, how satisfied } \\
\text { are you in general? (expert) }\end{array}$ & 0.80 \\
$2 \quad \begin{array}{l}\text { To what degree do you consider that Tun Hussein Onn Library fulfils your } \\
\text { expectations? (expect) }\end{array}$ & 0.77 \\
3 & $\begin{array}{l}\text { Imagine a library which is perfect in all aspects. How close to this ideal do } \\
\text { you consider Tun Hussein Onn Library to be? (perfect) }\end{array}$ & 0.77 \\
\hline
\end{tabular}

Alpha $=0.83$

\subsection{Construct Validation of User Loyalty to the Tun Hussein Onn Library (THOL) Exploratory Factor Analysis}

To assess the construct validity of the "user loyalty to the Tun Hussein Onn Library" construct, an exploratory factor analysis using principal component analysis was employed on the 3-item scale. Using a factor loading coefficient of 0.40 or greater as a criterion for deeming a factor loading as practically significant yielded a single factor solution (eigenvalue more than 1.00) that collectively explained $58.67 \%$ of the variance in the construct "user loyalty to the Tun Hussein Onn Library". The results of running the exploratory factor analysis using principal component analysis is visually depicted in Table 3 below.

Table 3. User loyalty to the Tun Hussein Onn Library (THOL)

\begin{tabular}{clc}
\hline No. & \multicolumn{1}{c}{ Items } & $\begin{array}{c}\text { Factor Loading } \\
\text { Coefficient }\end{array}$ \\
\hline 1 & Will you be using more of the library's services in the future? (future) & 0.83 \\
2 & Will you be using more of the library's resources in the future? (resource) & 0.85 \\
3 & $\begin{array}{l}\text { Will you recommend Tun Hussein Onn Library (THOL) to other users? } \\
\text { (other) }\end{array}$ & 0.59 \\
\hline
\end{tabular}

Percent of Variance Explained $=58.70 \%$. 


\subsection{Internal Reliability Test Using Cronbach's Alpha}

Before a new composite variable, is computed, the three-item scale was submitted to an internal reliability assessment test using Cronbach's internal reliability coefficient alpha. The results of running Cronbach's internal reliability test resulted in all the three items having a Cronbach's alpha vale of at 0.64 . Dropping item number three would result in the alpha value being raised to 0.72 . To ensure that the construct, "user loyalty to the Tun Hussein Onn Library" is internally reliable, item number three (Will you recommend Tun Hussein Onn Library (THOL) to other users?) was dropped. Hence, with only two items (future and resource) the internal reliability for the construct "user loyalty to the Tun Hussein Onn Library" becomes internally reliable with a Cronbach's alpha vale of 0.72 .

Table 4. Internal reliability assessment of user loyalty to the Tun Hussein Onn Library (THOL)

\begin{tabular}{clc}
\hline No. & \multicolumn{1}{c}{ Items } & $\begin{array}{c}\text { Cronbach's Alpha if Item is } \\
\text { Deleted }\end{array}$ \\
\hline 1 & Will you be using more of the library's services in the future? (future) & 0.45 \\
2 & $\begin{array}{l}\text { Will you be using more of the library's resources in the future? } \\
\text { (resource) }\end{array}$ & 0.40 \\
& $\begin{array}{l}\text { Will you recommend Tun Hussein Onn Library (THOL) to other } \\
\text { users? (other) }\end{array}$ & 0.72 \\
\hline
\end{tabular}

Alpha $=0.64$.

Subsequently, the two items (future and resource) were average to create a composite variable called user loyalty to the Tun Hussein Onn Library is now valued as well as internally reliable.

Table 5. Internal reliability assessment of user loyalty to the Tun Hussein Onn Library (THOL)

\begin{tabular}{clc}
\hline No. & \multicolumn{1}{c}{ Items } & $\begin{array}{c}\text { Cronbach's Alpha if Item is } \\
\text { Deleted }\end{array}$ \\
\hline 1 & $\begin{array}{l}\text { Will you be using more of the library's services in the future? } \\
\text { (future) }\end{array}$ & 0.51 \\
2 & $\begin{array}{l}\text { Will you be using more of the library's resources in the future? } \\
\text { (resource) }\end{array}$ & 0.63 \\
\hline
\end{tabular}

Alpha $=0.72$. 


\subsection{Independent Sample T-test}

The results of running an independent sample t-test showed that no statistically significant mean difference existed in user loyalty towards Tun Hussein Onn Library services, $\mathrm{t}(178)=$ $0.05, \mathrm{P}>.05$ between male $(\mathrm{M}=6.03, \mathrm{SD}=0.59)$ and female students $(\mathrm{M}=6.03, \mathrm{SD}=$ $0.61)$.

Table 6. Gender and user loyalty towards Tun Hussein Onn Library services

\begin{tabular}{cccccc}
\hline Gender & M & SD & df & t & Sig \\
\hline Male & 6.03 & 0.59 & 178 & 0.05 & 0.96 \\
Female & 6.03 & 0.61 & & & \\
\hline
\end{tabular}

\subsection{Independent Sample T-test}

The results of running an independent sample t-test showed that no statistically significant mean difference existed in user satisfaction towards Tun Hussein Onn Library services, $\mathrm{t}$ (178) $=0.35, \mathrm{P}>.05$ between male $(\mathrm{M}=6.16, \mathrm{SD}=0.59)$ and female students $(\mathrm{M}=6.13, \mathrm{SD}=$ $0.47)$.

Table 7. Gender and User Satisfaction towards Tun Hussein Onn Library Services

\begin{tabular}{cccccc}
\hline Gender & M & SD & df & t & Sig \\
\hline Male & 6.16 & 0.59 & 178 & 0.35 & 0.72 \\
Female & 6.13 & 0.47 & & & \\
\hline
\end{tabular}

\subsection{ONE-WAY ANOVA: Year of Study and User Loyalty}

The results of running a 1 way ANOVA showed that a statistically significant mean difference existed in user loyalty towards Tun Hussein Onn Library services, F $(2,177)=14.61$, P $<.001$ between first year students $(\mathrm{M}=6.35, \mathrm{SD}=0.36)$, second year students $(\mathrm{M}=5.77, \mathrm{SD}$ $=0.78)$ and those in the third year and above $(\mathrm{M}=6.14, \mathrm{SD}=0.36)$.

Table 8. ANOVA - Year of Study and User Loyalty towards Tun Hussein Onn Library Services 


\begin{tabular}{ccccc}
\hline Loyalty & SS & MS & F & Sig \\
\hline Between Group & 9.143 & 2 & 14.612 & .000 \\
Within Group & 55.373 & 177 & & \\
\hline Total & 64.515 & 179 & & \\
\hline
\end{tabular}

\subsection{ONE-WAY ANOVA: Year of Study and User Satisfaction}

The results of running a 1 way ANOVA showed that a statistically significant mean difference existed in user satisfaction towards Tun Hussein Onn Library services, F $(2,177)=18.68$, P $<.001$ between first year students $(\mathrm{M}=6.53, \mathrm{SD}=0.29)$, second year students $(\mathrm{M}=5.92, \mathrm{SD}$ $=0.63)$ and those in third year and above $(\mathrm{M}=6.17, \mathrm{SD}=0.37)$.

Table 9. ANOVA - Year of Study and User Satisfaction

\begin{tabular}{ccccc}
\hline User Satisfaction & SS & MS & F & Sig \\
\hline Between Group & 8.564 & 4.282 & 18.684 & .000 \\
Within Group & 40.565 & .229 & & \\
\hline Total & 49.129 & 4.511 & & \\
\hline
\end{tabular}

\subsection{ONE-WAY ANOVA: Students'Status and User Loyalty}

The results of running a one way ANOVA showed that no statistically significant mean difference existed in user loyalty towards Tun Hussein Onn Library services, F $(2,177)=$ $2.04, \mathrm{P}>.05$ between pre-university students $(\mathrm{M}=6.05, \mathrm{SD}=0.43)$, diploma level students $(\mathrm{M}=5.95, \mathrm{SD}=0.74)$ and baccalaureate level students $(\mathrm{M}=6.14, \mathrm{SD}=0.36)$.

Table 10. ANOVA - Students' Status and User Loyalty towards Tun Hussein Onn Library Services

\begin{tabular}{ccccc}
\hline User Loyalty & SS & MS & F & Sig \\
\hline Between Group & 1.456 & 0.728 & 2.04 & 0.13 \\
Within Group & 63.059 & 0.356 & & \\
\hline Total & 64.515 & 1.084 & & \\
\hline
\end{tabular}

\subsection{ONE-WAY ANOVA: Students'Status and User Satisfaction}

The results of running a one way ANOVA showed that no statistically significant mean 
difference existed in user satisfaction towards Tun Hussein Onn Library services, F $(2,177)=$ $3.22, \mathrm{P}>.05$ between pre-university students $(\mathrm{M}=6.50, \mathrm{SD}=0.37)$, diploma level students $(\mathrm{M}=6.08, \mathrm{SD}=0.61)$ and baccalaureate level students $(\mathrm{M}=6.17, \mathrm{SD}=0.38)$.

Table 11. ANOVA - Students' Status and User Satisfaction towards Tun Hussein Onn Library Services

\begin{tabular}{ccccc}
\hline User Satisfaction & SS & MS & F & Sig \\
\hline Between Group & 1.725 & 0.862 & 3.22 & 0.42 \\
Within Group & 47.404 & 0.268 & & \\
\hline Total & 49.129 & 1.130 & & \\
\hline
\end{tabular}

\section{Conclusion}

The results of this study provide partial support for the hypotheses that were formulated. The first hypothesis testing involved gender of students was found not to be statistically mean score differences with regard to users' satisfaction and users' loyalty dimensions. Previous studies showed that there were different results whether users' satisfaction and users' loyalty differed between male and female. Thus, more research and study needs to be conducted to confirm the results. Besides, the second hypothesis testing on years of study of the students revealed that differences existed on users' satisfaction and users' loyalty towards Tun Hussein Onn Library services. The findings suggested that year of study could have post-hoc test to confirm which years of study showed significant differences in mean score. The level of study was found not to be statistically mean score differences with regard to users' satisfaction and users' loyalty dimensions. More research regarding user satisfaction and user loyalty with level of study need to be done in the future. Furthermore, future study should include more target population of different groups. Instruments of questionnaire could be added with more items that could be modified and adopted from previous studies.

\section{References}

Abagai, T. (1993). The Use of Library in a Non-Residential College: A Case study of Kaduna State College of Education. Forum Academia. Multidisciplinary Journal of Education, 1(1), 104.

Adeniran, P. (2011). User satisfaction with academic libraries services: Academic staff and students perspectives, International Journal of Library and Information Science, 3(10), 209-216.

Andaleeb, S. S., \& Simmonds, L. P. (1998). Explaining user satisfaction with academic libraries: Strategic implications. College \& Research Libraries, 156-167. https://doi.org/10.5860/crl.59.2.156 
Berger, J., Conner, T. L., \& Fisek, M. H. (Eds.). (1974). Expectation states theory: A theoretical research program. Cambridge, MA; Winthrop.

Berger, J., Fisek, M. H., Norman, R., \& Zelditch, M. (1977). Status characteristics and social interaction. New York: Elsevier.

Bergman, E. M. L., \& Holden, I. I. (2010). User satisfaction with electronic reference: a systematic review. Reference Services Review, 38(3), 493-509. https://doi.org/10.1108/00907321011084789

Bhattacherjee, A. (2001a). Understanding information systems continuance: An expectation-confirmation model. MIS Quarterly, 25, 351-367. https://doi.org/10.2307/3250921

Cho, S. H., \& Hong, S. J. (2013). Blog user satisfaction: Gender differences in preferences and perception of visual design. Social Behavior and Personality: An International Journal, 41(8), 1319-1332. https://doi.org/10.2224/sbp.2013.41.8.1319

DeLone, W. H., \& McLean, E. R. (1992). Information systems success: The quest for the dependent variable. Information Systems Research, 3(1), 60-95. https://doi.org/10.1287/isre.3.1.60

Hekman, D., Aquino, K., Owens, B., Mitchell, T., Schilpzand, P., \& Leavitt, K. (2010). An examination of whether and how racial and gender biases influence customer satisfaction ratings. Academy of Management Journal, 53(2), 238-264. https://doi.org/10.5465/amj.2010.49388763

Klenke, K. (1992). Construct measurement in management information systems: A review and critique of user satisfaction and user involvement instruments. Information Systems and operations Research, 30, 325-348. https://doi.org/10.1080/03155986.1992.11732206

Kotler, P. (2006). Alphabet soup. Marketing Management, 15(2), 51-51.

Liu, C. H., \& Yen, L. C. (2010). The effects of service quality, tourism impact, and tourist satisfaction on tourist choice of leisure farming types. African Journal of Business Management, 4(8), 1529-1545.

Melone, N. P. (1990). A theoretical assessment of the user satisfaction construct in information systems research. Management Science, 36, 76-91. https://doi.org/10.1287/mnsc.36.1.76

Miller, L. (2004). User satisfaction surveys. Australasian Public Libraries and Information Services, 17(3), 125.

Niyonsenga, T., \& Biziman, B. (1996). Measures of library use and user satisfaction with academic library services. Library and Information Science Research, 18(3), 225-240. https://doi.org/10.1016/S0740-8188(96)90042-0

Kassim, N. A. (2009). Evaluating users' satisfaction on academic library performance. Malaysian Journal of Library \& Information Science, 14(2), 101-115. 


\section{Macrothink Institute ${ }^{\mathrm{TM}}$}

Ogunsola, M. O. (2004). Premarital behaviour and length of courtship as determinant of marital stability among couples in Oyo State, Nigeria. Unpublished M.Ed. project, University of Ibadan, Ibadan.

Ojo, R. A., \& Akande, S. O. (2005). Students access, usage and awareness of electronic information resources at University College Hospital, University of Ibadan, Nigeria. Lagos Journal of Library and Information Science, 1, 16-24.

Oliver, R. L. (1981). A cognitive model of the antecedents and consequences of satisfaction decisions. Journal of Marketing Research, 17, 460-469. https://doi.org/10.2307/3150499

Saliu, U. A. (2002). The development and roles of public libraries in Nigeria. Nigerian Libraries, 2(4), 45-51.

Seneviratne, D. (2006). Measuring user satisfaction: A case study at the PGIM branch library at Peradeniya. Journal of the University Librarians Association of Sri Lanka, 10, 40-53. https://doi.org/10.4038/jula.v10i0.317

Spärck Jones, K. (1981). Information Retrieval Experiment. Butterworths, London, 1981.

Tessier, J. A., Crouch, W. W., \& Atherton, P. (1977). New measures of user satisfaction with computer-based literature searches. Special Libraries, 68, 383-389.

Tyler, K., \& Hasting, N. B. (2011). Factors influencing virtual patron satisfaction with online library resources and services. The Journal of Educators Online, 8(2), 1-34. https://doi.org/10.9743/JEO.2011.2.3

Walton, G., \& Leahy, F. (2013). Loughborough university library users'satisfaction survey 2012. Viewed on $15 \quad$ May 2014 at www.lboro.ac.uk/media/wwwlboroacuk/content/library/downloads/surveyresults/Library\%20 general\%20user\%20survey\%20(2012).pdf

Wherry Sr., R. J., \& Bartlett, C. J. (1982). The control of bias in ratings: A theory of rating. Personnel Psychology, 35, 521-551. https://doi.org/10.1111/j.1744-6570.1982.tb02208.x

Wright, S. M., Craig, T., Campbell, S., Shaefer, J., \& Humble, C. (2006). Patient satisfaction of female and male users of Veterans Health Administration services. Journal of Genetic International Medical, 21(3), 26-32. https://doi.org/10.1111/j.1525-1497.2006.00371.x

Woo, H. (2005). The 2004 survey at the University of Hong Kong libraries. College and Research Libraries, 1-20 https://doi.org/10.5860/crl.66.2.115.

\section{Copyright Disclaimer}

Copyright for this article is retained by the author(s), with first publication rights granted to the journal.

This is an open-access article distributed under the terms and conditions of the Creative Commons Attribution license (http://creativecommons.org/licenses/by/4.0/). 